\title{
Analysis of genetic diversity of 100 cashew (Anacardium occidentale L.) cultivars screened in Binh Phuoc based on nut yield and ISSR markers
}

Toan D. Pham $^{1 *}$, Duc M. Tran ${ }^{2}$, Thu T. Nguyen ${ }^{1}, \&$ Tri M. Bui ${ }^{3}$

${ }^{1}$ Research Institute of Biotechnology and Environment, Nong Lam University, Ho Chi Minh City, Vietnam

${ }^{2}$ Binh Phuoc High-Tech Agriculture Research Center, Binh Phuoc, Vietnam

${ }^{3}$ Faculty of Agronomy, Nong Lam University, Ho Chi Minh City, Ho Chi Minh City, Vietnam

ARTICLE INFO
Research Paper
Received: December 18, 2019
Revised: February 19, 2020
Accepted: April 21, 2020
Keywords
Cashew variety
Conservation
Genetic diversity
ISSR
Plant breeding
*Corresponding author
Pham Duc Toan
Email: phamductoan@hcmuaf.edu.vn

Cited as: Pham, T. D., Tran, D. M., Nguyen, T. T., \& Bui, T. M. (2020). Analysis of genetic diversity of 100 cashew (Anacardium occidentale L.) cultivars screened in Binh Phuoc based on nut yield and ISSR markers. The Journal of Agriculture and Development 19(2), 17-27.

\begin{abstract}
Cashew (Anacardium occidentale L.) is an important tropical tree, belonging to Anacardiaceae family and has high economic value growing in Vietnam. The objective of this study was to assess genetic diversity of cashew distributed in Binh Phuoc province for breeding development and conservation. A total of 100 cashew samples of over 10 years age distributed in Binh Phuoc province were divided into eight main groups based on nut yield. In contrast, the cluster analysis was divided 100 cashew samples into 12 groups based on 11 ISSR markers. The genetic diversity of 100 cashew samples ranged from 0.04 to 0.26 , with a mean of 0.19 . The results showed that cashew samples were high levels of polymorphism based on nut yield, as well as the ISSR markers. The results of this research would be one of the important information in the genetic evaluation of cashew trees and useful information for cashew breeding development in future.
\end{abstract}




\title{
Phân tích đa dạng di truyền 100 mẫu giống điều (Anacardium occidentale L.) được tuyển chọn trên địa bàn tỉnh Bình Phước dựa trên năng suất hạt và chỉ thị sinh học phân tử ISSR
}

\author{
Phạm Đức Toàn ${ }^{1 *}$, Trần Minh Đức ${ }^{2}$, Nguyễn Thị Thu ${ }^{1} \&$ Bùi Minh Trí ${ }^{3}$ \\ ${ }^{1}$ Viện Nghiên Cứu Công Nghệ Sinh Học và Môi Trường, Trường Đại Học Nông Lâm TP.HCM, \\ TP. Hồ Chí Minh \\ ${ }^{2}$ Trung Tâm Nông Nghiệp Ứng Dụng Công Nghệ Cao Tỉnh Bình Phước, Bình Phước \\ ${ }^{3}$ Khoa Nông Học, Trường Đại Học Nông Lâm TP.HCM, TP. Hồ Chí Minh
}

\section{THÔNG TIN BÀI BÁO}

Bài báo khoa học

Ngày nhận: 18/12/2019

Ngày chỉnh sửa: 19/02/2020

Ngày chấp nhận: 21/04/2020

Từ khóa

Bảo tồn

Đa dạng di truyền

Giống điều

ISSR

Nhân giống

*Tác giả liên hệ

Phạm Đức Toàn

Email: phamductoan@hcmuaf.edu.vn

\section{TÓM TẮT}

Cây điều (Anacardium occidentale L.) là cây nhiệt đới quan trọng, thuộc họ Anacardiaceae và có giá trị kinh tế cao được trồng ở Việt Nam. Mục đích của nghiên cứu này nhằm đánh giá, phân nhóm đa dạng di truyền của các mẫu giống điều phân bố trên địa bàn tỉnh Bình Phước nhằm phục vụ cho công tác phát triển nhân giống và bảo tồn. Tổng số 100 mẫu giống điều trên 10 năm tuổi phân bố trên địa bàn tỉnh Bình Phước được phân chia thành 8 nhóm chính dựa trên đặc điểm hạt và năng suất hạt. Trong khi đó, khi sử dụng 11 chỉ thị ISSR thì các mẫu giống điều được chia thành 12 nhóm riêng biệt. Khoảng cách đa dạng di truyền 100 mẫu giống điều trong nghiên cứu này từ 0,04 đến 0,26 , với giá trị trung bình khoản cách đa dạng di truyền 0,19 . Kết quả thể hiện các mẫu giống điều có mức đa hình tương đối cao dựa trên đặc điểm hạt và năng suất hạt, cũng như chỉ thị ISSR. Kết quả nghiên cứu này là một trong những thông tin rất quan trọng trong công tác đánh giá di truyền trên cây điều và hữu ích cho công tác chọn tạo và phát triển giống điều trong tương lai.

\section{1. Đặt Vấn Đề}

Cây điều (Anacardium occidentale L.) là cây nhiệt đới lấy hạt quan trọng, thuộc họ Anacardiaceae và có nguồn gốc tự nhiên ở các quốc gia Nam Mỹ như Bolivia, Brazil, Peru và Tây Ấn Độ (Nakasone \& Paull, 1998; Samal \& ctv., 2003). Trong họ Anacardiaceae bao gồm 75 chi (genera) và 700 loài (species) (Nakasone \& Paull, 1998). Trong đó, cây điều ( $A$. occidentale) có khả năng chịu hạn, sinh trưởng tốt trên các loại đất đồi dốc và là cây có giá trị kinh tế giúp ổn định đời sống người nghèo (Aliyu, 2012). Bình Phước là một trong những địa phương có điều kiện thổ nhưỡng thích hợp cho cây điều phát triển với diện tích và sản lượng vượt trội hơn các địa phương khác của cả nước.
Việc trồng điều mang một ý nghĩa chiến lược vì không những tận dụng được địa hình đồi dốc mà còn cải thiện đời sống cho người dân do xuất khẩu mang lại ngoại tệ cao. Tuy nhiên, hiện nay quá trình phát triển cây điều ở Việt Nam nói chung và Đông Nam Bộ nói riêng đang gặp nhiều khó khăn và chưa ổn định. Nguyên nhân chủ yếu của sự trở ngại này do giống điều trồng trong sản xuất chưa phù hợp với điều kiện tự nhiên, tiêu chuẩn hạt chưa phù hợp với yêu cầu của chế biến, chịu tác động mạnh của yếu tố khí hậu và thời tiết không thuận lợi. Mặc dù đã có nhiều đơn vị trong nước đã tiến hành tuyển chọn và cải tiến các giống điều để đưa vào sản xuất nhưng năng suất còn thấp và còn nhiều khuyết điểm khi áp dụng vào sản suất.

Mục đích của nghiên cứu này nhằm đánh giá, 
phân nhóm đa dạng di truyền của các mẫu giống điều phân bố trên địa bàn tỉnh Bình Phước dựa trên chỉ tiêu năng suất hạt, số hạt khô/kg và chỉ thị sinh học phân tử ISSR, nhằm phục phục vụ cho công tác phát triển nhân giống và bảo tồn.

\section{Vật Liệu và Phương Pháp Nghiên Cứu}

\subsection{Khảo sát chỉ tiêu hạt, năng suất hạt và li trích DNA dùng cho phản ứng PCR-ISSR}

Tổng số 100 mẫu giống điều trên 10 năm tuổi phân bố trên địa bàn tỉnh Bình Phước được khảo sát đánh giá các chỉ tiêu năng suất hạt và số hạt khô $/ \mathrm{kg}$ (Bảng 1). Mẫu lá của 100 mẫu giống điều cũng được thu thập để li trích DNA phục vụ cho công tác đánh giá đa dạng di truyền bằng chỉ thị ISSR. DNA của các mẫu giống điều được li trích bằng quy trình $\mathrm{CTAB}$, mẫu được li trích là mẫu lá non. Phản ứng PCR-ISSR được thực hiện trong thể tích $25 \mu \mathrm{L}$ bao gồm $1 \mathrm{X}$ MasterMix (Bioline - UK), 0,2 $\mu \mathrm{M}$ primer ISSR, $1 \mu \mathrm{L}$ DNA (khoảng 50-100 ng/ $\mathrm{L}$ ), và nước cất khử ion vừa đủ $25 \mu \mathrm{L}$. Phản ứng PCR-ISSR được thực hiện trên máy PCR (Applied Biosystems 9700) với chu trình nhiệt như sau 1 chu kỳ của $94^{\circ} \mathrm{C}$ trong 5 phút; 30 chu kỳ của $94^{\circ} \mathrm{C}-1$ phút, $55^{\circ} \mathrm{C}-2$ phút, $72^{\circ} \mathrm{C}-2$ phút; 1 chu kỳ của $72^{\circ} \mathrm{C}-5$ phút và cuối cùng là giữ sản phẩm PCR-ISSR ở $4^{\circ} \mathrm{C}$.

Điện di kiểm tra sản phẩm PCR-ISSR trên gel agarose với nồng độ $1,5 \%$. Sau khi điện di, gel được chụp hình trên máy chiếu sáng bằng UV. Để ước lượng kích thước trình tự các đoạn DNA khuếch đại trong gel agarose, dùng thang chuẩn ladder $1 \mathrm{~Kb}$ DNA (Bioline - UK).

\subsection{Phân nhóm di truyền}

Sử dụng phần mềm MiniTab 16.0 để đánh giá và phân nhóm di truyền của 100 mẫu giống đều dựa vào chỉ tiêu năng suất hạt và số hạt $/ \mathrm{kg}$. Đối với chỉ thị ISSR, từ kết quả điện di của sản phẩm PCR - ISSR, tiến hành xác định mức độ đa hình của các mẫu bằng cách so sánh các phân đoạn DNA. Các phân đoạn DNA được ghi nhận: nếu xuất hiện band trong sản phẩm điện di ở cùng kích thước được kí hiệu 1, không xuất hiện thì kí hiệu 0. Các số liệu này sẽ được xử lí và phân tích bằng phần mềm NTSYSpc 2.1 (Numerial Taxonomy System) để tìm ra mối liên quan giữa các đối tượng nghiên cứu thông qua hệ số đa hình di truyền và biểu đồ hình cây phân nhóm.

\section{Kết Quả và Thảo Luận}

\subsection{Khảo sát chỉ tiêu về hạt và năng suất hạt của các giống điều tại tỉnh Bình Phước}

Trong tổng số 100 mẫu giống điều trên 10 năm tuổi đã được khảo sát chỉ tiêu năng suất hạt và số hạt khô/kg. Kết quả được ghi nhận cho thấy năng suất hạt của các mẫu giống điều dao động từ $30-100 \mathrm{~kg} /$ cây $/$ năm, năng suất trung bình là $47 \mathrm{~kg} /$ cây/năm. Số hạt khô/kg của các mẫu giống điều có mức dao động từ 109 - 224 hạt $/ \mathrm{kg}$, trung bình 156 hạt khô/kg (Bảng 1).

\subsection{Phân nhóm các mẫu giống điều dựa vào đặc điểm hạt và năng suất hạt}

Dựa vào các đặc điểm hạt và năng suất hạt/cây/năm của các giống điều có thể thấy 100 mẫu giống điều được khảo sát, thu thập phân chia vào 8 nhóm chính (Bảng 2 , Hình 1 ). Trong đó nhóm $\mathrm{V}$ là nhóm lớn nhất bao gồm 32 mẫu giống, và nhóm ít mẫu giống nhất là nhóm VII với chỉ duy nhất 1 mẫu giống. Các nhóm được thể hiện chi tiết trong Bảng 2.

\section{3. Đánh giá sự phân nhóm di truyền của 100 mẫu giống điều dựa vào chỉ thị ISSR}

Với tổng số 30 primer ISSR sử dụng để sàng lọc lựa chọn ra các primer đa hình phục vụ cho đánh giá sự đa hình của các mẫu giống điều. Trong đó sàng lọc ra 11 primer ISSR cho cho sản phẩm khuyếch đại đa hình tốt, tỉ lệ băng đa hình cao do đó đã được lựa chọn sử dụng cho đánh giá đa hình di truyền cây điều. Tổng số sản phẩm khuếch đại từ 11 ISSR primer 113 band, đạt trung bình 10,3 band/primer, kích thước band từ 200 - 3000 bp (Bảng 3). Tổng số đoạn khuếch đại đa hình 101 band, trung bình 9,2 band/primer, tỉ lệ band đa hình $88,3 \%$. Primer cho nhiều đoạn khuếch đại nhất là primer UBC841 (13 band) và số đoạn đa hình đạt được cũng là 13 band, đạt tỉ lệ 100\% band đa hình. Primer có số band thấp nhất là UBC808 (7 band), nhưng tất cả đều là band đa hình, tỉ lệ đạt 100\%. Trong 11 primer được lựa chọn, tỉ lệ đoạn khuếch đại đa hình thấp nhất là primer UBC888, với tỉ lệ đa hình chỉ 60\% (6/10 band đa hình). Các primer cho đa hình tuyệt đối $100 \%$ bao gồm các primer sau UBC808, UBC841, UBC873, UBC880, UBC855 (Hình 2). Nhìn chung tất cả các primer ISSR được chọn sử dụng cho nghiên cứu cây điều có mức độ đa hình 
Bảng 1. Kết quả khảo sát chỉ tiêu năng suất hạt và số hạt khô/kg của 100 mẫu giống điều

\begin{tabular}{|c|c|c|c|c|}
\hline STT & Mã số mẫu giống & Địa điểm thu thập mẫu & $\begin{array}{c}\text { Năng suất } \\
\mathrm{kg} / \text { cây/năm }\end{array}$ & $\begin{array}{l}\text { Số hạt } \\
\text { khô/kg }\end{array}$ \\
\hline 1 & MD1 & Ấp 8, Tiến thành, Đồng Xoài & 50 & 121 \\
\hline 2 & MD2 & ÂP 4, Tiến Hưng, Đồng Xoài & 40 & 159 \\
\hline 3 & MD3 & ÂP 4, Tiến Hưng, Đồng Xoài & 50 & 160 \\
\hline 4 & MD4 & Ấp 1, xã Đồng Tâm - Đồng Phú & 30 & 130 \\
\hline 5 & MD5 & Ấp 1, xã Đồng Tâm - Đồng Phú & 35 & 165 \\
\hline 6 & MD6 & Phú Thành - Phú Riềng -Bù Gia Mập & 70 & 170 \\
\hline 7 & MD7 & Phú Thành- Phú Riềng - Bù Gia Mập & 50 & 133 \\
\hline 8 & MD8 & Ấp Minh Tân - Tân Tiến - Đồng Phú & 100 & 174 \\
\hline 9 & MD9 & Âp Minh Tân - Tân Tiến- Đồng Phú & 70 & 173 \\
\hline 10 & MD10 & Ấp Minh Tân - Tân Tiến - Đồng Phú & 70 & 175 \\
\hline 11 & MD11 & Âp Thuận Phú- Thuận Phú - Đồng Phú & 90 & 190 \\
\hline 12 & MD12 & Ấp Thuận Phú - Thuận Phú - Đồng Phú & 60 & 172 \\
\hline 13 & MD13 & Thôn 7, xã Bình Minh - Bù Đăng & 70 & 159 \\
\hline 14 & MD14 & Thôn 7, xã Bình Minh - Bù Đăng & 50 & 164 \\
\hline 15 & MD15 & Thôn Đồng Tiến - Phước Tân - Bù Gia Mập & 60 & 170 \\
\hline 16 & MD16 & Thôn Đồng Tiến - Phước Tân - Bù Gia Mập & 50 & 155 \\
\hline 17 & MD17 & Thôn 10 TN, Bù Đăng & 60 & 156 \\
\hline 18 & MD18 & Thôn 10 TN, Bù Đăng & 45 & 196 \\
\hline 19 & MD19 & Thôn 10 TN, Bù Đăng & 55 & 180 \\
\hline 20 & MD20 & Thôn 10 TN, Bù Đăng & 62 & 144 \\
\hline 21 & MD21 & Thôn 10 TN, Bù Đăng & 50 & 188 \\
\hline 22 & MD22 & Thôn 3 TN, Bù Đăng & 60 & 149 \\
\hline 23 & MD23 & Đức Liễu, Bù Đăng & 50 & 224 \\
\hline 24 & MD24 & Đức Liễu, Bù Đăng & 50 & 156 \\
\hline 25 & MD25 & Đức Liễu, Bù Đăng & 55 & 140 \\
\hline 26 & MD26 & Ấp Tân Lập, xã Phú Nghĩa, Bù Gia Mập & 30 & 196 \\
\hline 27 & MD27 & Ấp Tân Lập, xã Phú Nghĩa, Bù Gia Mập & 52 & 141 \\
\hline 28 & MD28 & Ấp cây da, xã Phú Văn - Bù Gia Mập & 45 & 124 \\
\hline 29 & MD29 & Ấp Cây Da, xã Phú Văn - Bù Gia Mập & 50 & 175 \\
\hline 30 & MD30 & Ấp Cây Da, xã Phú Văn, Bù Gia Mập & 45 & 145 \\
\hline 31 & MD31 & Thôn 3 - ĐakƠ - Bù Gia Mập & 50 & 170 \\
\hline 32 & MD32 & Thôn 6 - ĐakƠ - Bù Gia Mập & 55 & 168 \\
\hline 33 & MD33 & Thôn 6 - ĐakỎ-BGM & 60 & 186 \\
\hline 34 & MD34 & Ấp 7, xã Bom Bo - Bù Gia Mập & 55 & 221 \\
\hline 35 & MD35 & Thôn 7, xã Bình Minh - Bù Đăng & 60 & 208 \\
\hline 36 & MD36 & Ấp 7, xã Bom Bo - Bù Gia Mập & 55 & 188 \\
\hline 37 & MD37 & Phước Tân - Phước Tân - Bù Gia Mập & 55 & 116 \\
\hline 38 & MD38 & Phước Tân - Phước Tân - Bù Gia Mập & 45 & 120 \\
\hline 39 & MD39 & Thôn 2- Long Bình - Bù Gia Mập & 55 & 160 \\
\hline 40 & MD40 & Thôn Đakon - Bù Gia Mập & 45 & 145 \\
\hline 41 & MD41 & Thôn Đakon, Bù Gia Mập & 48 & 135 \\
\hline 42 & MD42 & Thôn Đakon, Bù Gia Mập & 50 & 148 \\
\hline 43 & MD43 & Thôn Đakon, Bù Gia Mập & 50 & 140 \\
\hline 44 & MD44 & Tổ 3 - phường Thác Mơ, Phước Long & 30 & 155 \\
\hline 45 & MD45 & Tổ 3 - phường Thác Mơ, Phước Long & 40 & 185 \\
\hline
\end{tabular}


Bảng 1. Kết quả khảo sát chỉ tiêu năng suất hạt và số hạt khô/kg của 100 mẫu giống điều (tiếp theo trang 20)

\begin{tabular}{|c|c|c|c|c|}
\hline STT & Mã số mẫu giống & Địa điểm thu thập mẫu & $\begin{array}{c}\text { Năng suất } \\
\text { kg/cây/năm }\end{array}$ & $\begin{array}{l}\text { Số hạt } \\
\text { khô/kg }\end{array}$ \\
\hline 46 & MD46 & Âp 10, xã Long Hà - Bù Gia Mập & 70 & 176 \\
\hline 47 & $\mathrm{MD} 47$ & Âp 10, xã Long Hưng - Bù Gia Mập & 30 & 164 \\
\hline 48 & MD48 & Âp 7, xã Bình Minh - Bù Đăng & 40 & 150 \\
\hline 49 & MD49 & Âp 7, xã Bom Bo - Bù Gia Mập & 50 & 140 \\
\hline 50 & MD50 & Thôn 2 căn - Phú Nghĩa - Bù Gia Mập & 50 & 131 \\
\hline 51 & MD51 & Thôn 2 căn - Phú Nghĩa - Bù Gia Mập & 60 & 154 \\
\hline 52 & MD52 & Thôn 2 căn - Phú Nghĩa - Bù Gia Mập & 55 & 164 \\
\hline 53 & MD53 & Tân Phước - Đồng Phú & 50 & 145 \\
\hline 54 & MD54 & Tân Phước - Đồng Phú & 35 & 124 \\
\hline 55 & MD55 & Tân Phước - Đồng Phú & 40 & 146 \\
\hline 56 & MD56 & Tân Phước - Đồng Phú & 45 & 120 \\
\hline 57 & MD57 & Tân Phước - Đồng Phú & 40 & 140 \\
\hline 58 & MD58 & Tân Phước - Đồng Phú & 55 & 109 \\
\hline 59 & MD59 & Tân Phước - Đồng Phú & 40 & 100 \\
\hline 60 & MD60 & Tân Phước - Đồng Phú & 40 & 148 \\
\hline 61 & MD61 & Tân Phước - Đồng Phú & 52 & 144 \\
\hline 62 & MD62 & Minh Lập - Chơn Thành & 70 & 120 \\
\hline 63 & MD63 & Minh Lập - Chơn Thành & 60 & 124 \\
\hline 64 & MD64 & Minh Lập - Chơn Thành & 40 & 122 \\
\hline 65 & MD65 & Âp 1 - Tân Lập - Đồng Phú & 40 & 170 \\
\hline 66 & MD66 & Thông 10 - Long Bình - Phú Riềng & 45 & 198 \\
\hline 67 & MD67 & Thôn 8- Long Hà, Phú Riềng & 70 & 133 \\
\hline 68 & MD68 & Thôn 8- Long Hà, Phú Riềng & 60 & 124 \\
\hline 69 & MD69 & Thôn 10- Long Bình- Phú Riềng & 40 & 173 \\
\hline 70 & MD70 & Thanh Phú - Bình Long & 40 & 150 \\
\hline 71 & MD71 & Thanh Phú - Bình Long & 40 & 150 \\
\hline 72 & MD72 & Tổ 5 - Bù Anh - Thanh An & 50 & 145 \\
\hline 73 & MD73 & Tổ 5 - Bù Anh - Thanh An & 40 & 155 \\
\hline 74 & MD74 & Tổ 9 - Âp Trung Sơn - Thanh An & 50 & 170 \\
\hline 75 & MD75 & Tổ 9 - An Sơn - Thanh An & 40 & 175 \\
\hline 76 & MD76 & & 30 & 160 \\
\hline 77 & MD77 & & 35 & 140 \\
\hline 78 & MD78 & & 30 & 145 \\
\hline 79 & MD79 & & 40 & 160 \\
\hline 80 & MD80 & & 30 & 165 \\
\hline 81 & MD81 & & 30 & 155 \\
\hline 82 & MD82 & Vườn bảo tồn thuộc Ban quản lý & 40 & 170 \\
\hline 83 & MD83 & khư Nôno nohiên Úng dung & 40 & 140 \\
\hline 84 & MD84 & khu Nông nghlẹp Ung dụng & 35 & 150 \\
\hline 85 & MD85 & Công nghệ cao tỉnh Bình Phước & 35 & 165 \\
\hline 86 & MD86 & Âp 8 - Tân Thành - Đồng Xoài - Bình Phước & 40 & 170 \\
\hline 87 & MD87 & & 30 & 140 \\
\hline 88 & MD88 & & 40 & 135 \\
\hline 89 & MD89 & & 45 & 145 \\
\hline 90 & MD90 & & 35 & 145 \\
\hline 91 & MD91 & & 30 & 150 \\
\hline 92 & MD92 & & 50 & 160 \\
\hline
\end{tabular}


Bảng 1. Kết quả khảo sát chỉ tiêu năng suất hạt và số hạt khô/kg của 100 mẫu giống điều (tiếp theo trang 21)

\begin{tabular}{|c|c|c|c|c|}
\hline STT & Mã số mẫu giống & Địa điểm thu thập mẫu & $\begin{array}{l}\text { Năng suất } \\
\mathrm{kg} / \mathrm{cây} / \text { năm }\end{array}$ & $\begin{array}{l}\text { Số hạt } \\
\text { khô/kg }\end{array}$ \\
\hline 93 & MD93 & \multirow{3}{*}{ Vườn bảo tồn thuộc Ban quản lý } & 50 & 175 \\
\hline 94 & MD94 & & 40 & 170 \\
\hline 95 & MD95 & & 30 & 140 \\
\hline 96 & MD96 & \multirow{5}{*}{$\begin{array}{c}\text { khu Nông nghiệp Ưng dụng } \\
\text { Công nghệ cao tỉnh Bình Phước }\end{array}$} & 30 & 135 \\
\hline 97 & MD97 & & 35 & 140 \\
\hline 98 & MD98 & & 30 & 160 \\
\hline 99 & MD99 & & 30 & 160 \\
\hline 100 & MD100 & & 35 & 156 \\
\hline \multicolumn{2}{|c|}{ Cao nhất } & & 100 & 244 \\
\hline \multicolumn{2}{|c|}{ Trung bình } & & 30 & 109 \\
\hline \multicolumn{2}{|c|}{ Thấp nhất } & & 47 & 156 \\
\hline
\end{tabular}

Bảng 2. Phân nhóm các mẫu giống điều dựa vào đặc điểm hạt và năng suất hạt

\begin{tabular}{lll}
\hline Nhóm & Tên mẫu giống (MD) & Ghi chú mẫu trội \\
\hline I & $35,34,23$ & 23 \\
II & $33,36,21,19,26,45,66,18$ & 11 \\
III & 11,8 & \\
IV & $46,10,9,6,22,50,51,17,13,74,31,93,29,32,15,12,24,16,52$, & $6,12,15,24,46$ \\
& $39,14,92,3$ & \\
V & $61,72,53,42,89,40,30,49,43,27,25,41,50,7,91,84,90,78,60$, & $43,70,71,72$ \\
& $55,71,70,48,96,95,67,97,77,88,83,57,4$ & 62,73 \\
VI & $76,69,94,86,62,65,100,61,44,99,98,76,80,4,65,5,73,79,2$ & 63,64 \\
VII & 59 & \\
VIII & $67,68,63,58,37,64,54,56,38,28,1$ & \\
\hline
\end{tabular}
MD: Mẫu điều.

Bảng 3. Kết quả đánh giá đa hình của 11 primer ISSR trên 100 mẫu giống điều Bình Phước

\begin{tabular}{clcccc}
\hline Tên primer & Trình tự primer & $\begin{array}{c}\text { Tổng số band } \\
\text { khuếch đại }\end{array}$ & $\begin{array}{c}\text { Tổng số band } \\
\text { đa hình }\end{array}$ & $\begin{array}{c}\text { Tỷ lệ đa } \\
\text { hình }(\%)\end{array}$ & $\begin{array}{c}\text { Kích thước } \\
\text { đoạn khuếch } \\
\text { đại (bp) }\end{array}$ \\
\hline UBC808 & (AG)8C & 7 & 7 & 100 & $200-2500$ \\
UBC810 & (GA)8T & 9 & 8 & 89 & $350-1500$ \\
UBC811 & (GA)8C & 11 & 10 & 91 & $250-3000$ \\
UBC825 & (AC)8T & 8 & 5 & 63 & $250-1700$ \\
UBC840 & (GA)8YT & 11 & 10 & 91 & $400-300$ \\
UBC841 & (GA)8YC & 13 & 13 & 100 & $350-3000$ \\
UBC850 & (GT)8YC & 9 & 12 & 78 & $200-3000$ \\
UBC855 & (AC)8YT & 12 & 12 & 100 & $200-6000$ \\
UBC873 & (GACA)4 & 12 & 11 & 100 & $200-3000$ \\
UBC880 & (GGAGA)3 & 11 & 6 & 60 & $300-3000$ \\
UBC888 & BDB(CA)7 & 10 & 9,2 & 88,3 & $250-3000$ \\
\hline Trung bình & & 10,3 & 101 & & $2000-3000$ \\
Tổng số & & 113 & $5-12$ & $63-100$ & 2000 \\
Biến động & & $7-13$ & & & \\
\hline
\end{tabular}




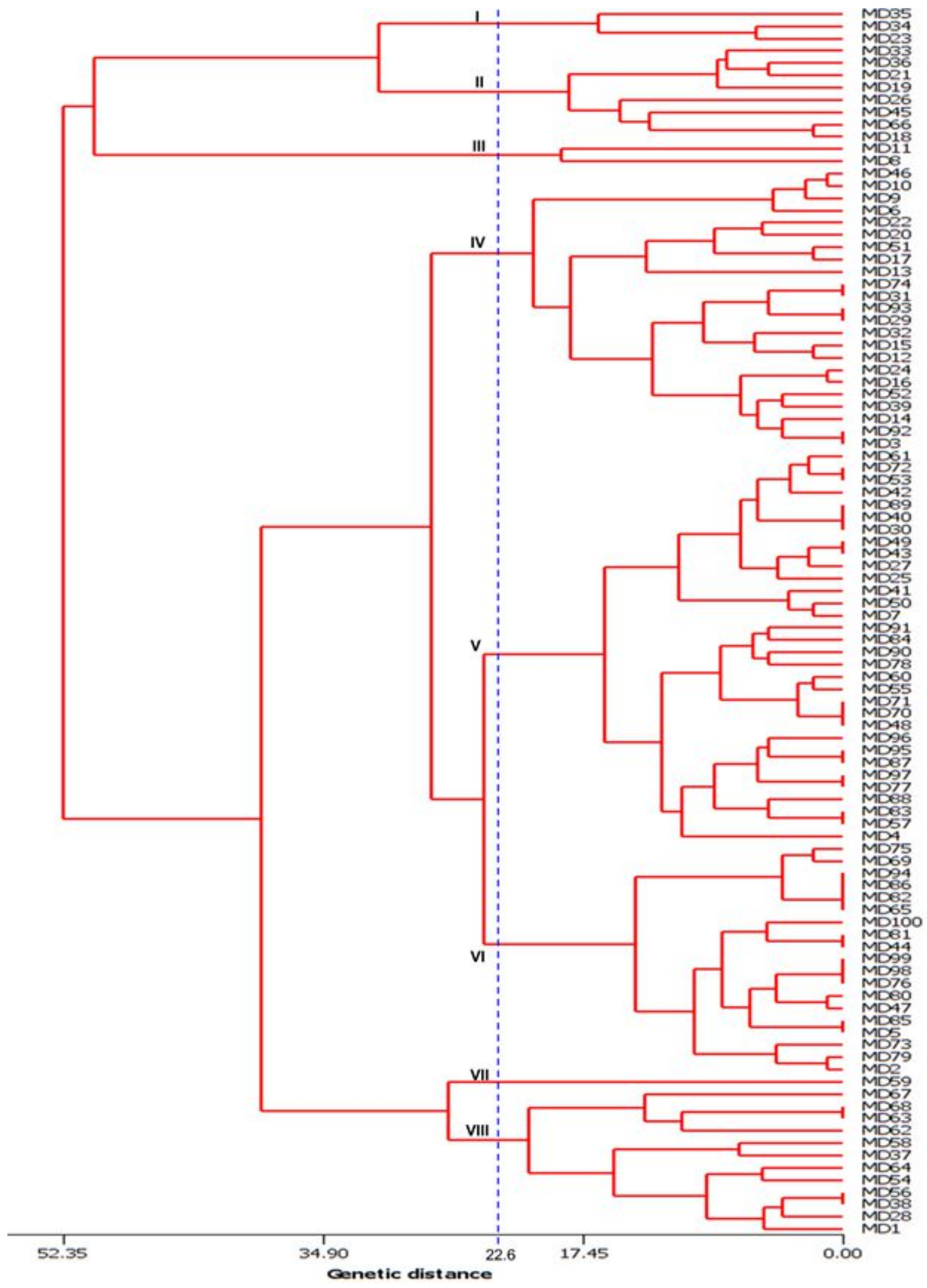

Hình 1. Kết quả phân nhóm 100 mẫu giống điều dựa vào chỉ tiêu hạt và năng suất hạt. 
Bảng 4. Kết quả phân nhóm di truyền của 100 mẫu giống điều dựa trên chỉ thị ISSR

\begin{tabular}{lll}
\hline Nhóm & Tên mẫu giống MD (mẫu điều) & Ghi chú (Các mẫu giống nổi trội) \\
\hline I & $1,4, \mathbf{1 5}, \mathbf{2 4}, 26,27,17,35,34,7,30,21, \mathbf{2 3}, \mathbf{6}, 8$, & $15,24,7,23,6,12,11,46,43,63$, \\
& $10, \mathbf{1 2}, \mathbf{1 1}, 42,16,32,38,41,47,44,45, \mathbf{4 6}, 19$, & 64,62 \\
& $29,18,20, \mathbf{4 3}, 25,28,66, \mathbf{6 3}, \mathbf{6 4}, 66,9,52,54$, & \\
& $37,35,13,31,33, \mathbf{6 2}, 65,40,48,49,51$ & \\
II & $14,22,61,55,56,36$ & 72 \\
III & $2, \mathbf{7 2}$ & 73 \\
IV & $39,50, \mathbf{7 3}$ & 71 \\
V & $67, \mathbf{7 1}$ & \\
VI & 59 & Bộ sưu tập giống, trồng tại Ban \\
VII & $76,77,78,79,81,85,86,82,83,84,87,88,80,89$, & quản lý khu Nông nghiệp Ứng \\
& $90,92,98,96,95,93,94,91,97,99,100$ & dụng Công nghệ cao tỉnh Bình \\
& & Phước \\
VIII & 74,75 & 74,75 \\
IX & 53 & \\
X & 57,58 & \\
XI & 60,69 & \\
XII & 70 & 70 \\
\hline
\end{tabular}

MD: Mẫu điều; các số theo sau là ký hiệu số mẫu theo thứ tự từ 1 - 100, bắt đầu từ 1.

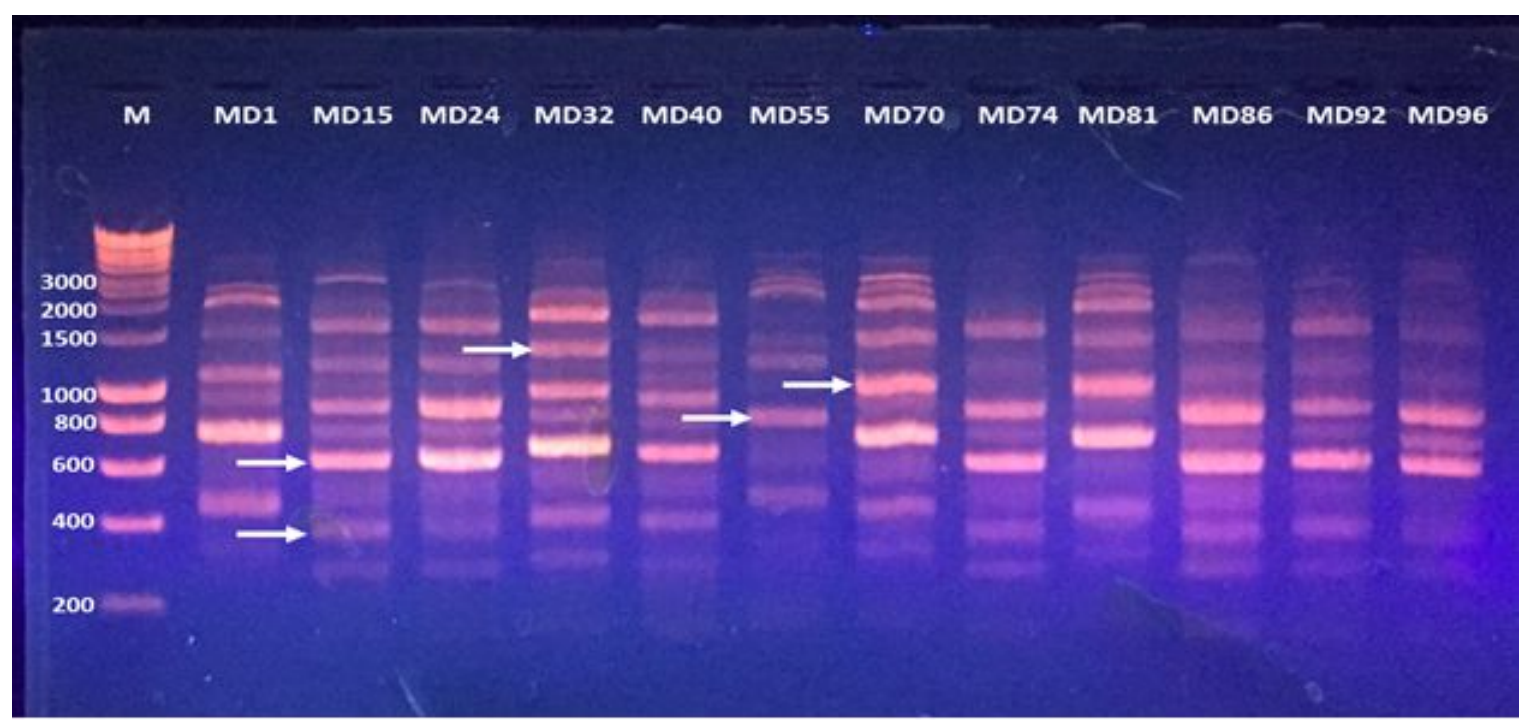

Hình 2. Sản phẩm khuếch đại của các mẫu giống điều với primer UBC855.

M: thang chuẩn $1 \mathrm{~kb} \mathrm{DNA}$, các mẫu còn lại là mẫu điều theo số thứ tự (MD: Mẫu điều; các số theo sau là số thứ tự của 100 mẫu giống điều, bắt đầu từ số 1). Dấu mũi tên chỉ ra vài vị trí đại diện đa hình.

khá cao, dao động từ 60 - 100\%, đáp ứng đầy đủ và tin cậy cao trong phân tích đa hình di truyền cây điều.

Kết quả nghiên cứu này cũng cho thấy các chỉ thị ISSR khá hiệu quả trong sử dụng phân tích đa dạng di truyền cây điều. Với mức độ đa hình của 11 chỉ thị ISSR trên 100 mẫu giống diều là
88,3\%, kết quả này cũng khá phù hợp với báo cáo của tác giả Santhosh \& ctv. (2009) trên 100 mẫu giống điều khi sử dụng 10 chỉ thị ISSR thu được 67 đoạn khuếch đại, trong đó có 58 đoạn đa hình, chiếm tỉ lệ 86,6\%. Tương tự, báo cáo của Dasmohapatra \& ctv. (2014) cũng đã chỉ ra rằng khi phân tích đa dạng di truyền của 25 mẫu 


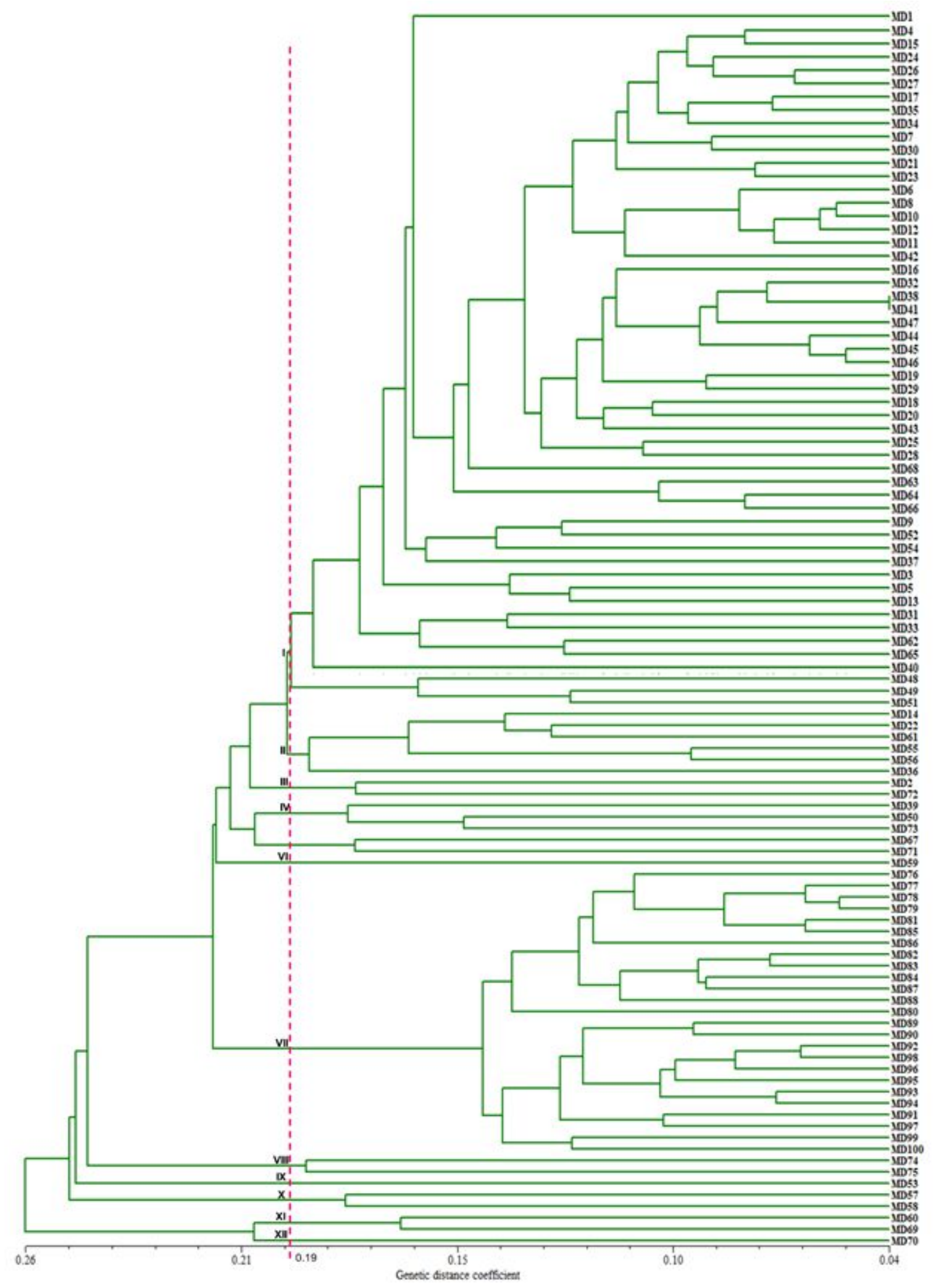

Hình 3. Cây phân nhóm di truyền của 100 mẫu giống điều dựa trên 11 chỉ thị ISSR. 
giống điều được phục tráng ở Ấn Độ bằng 14 chỉ thị ISSR thu được tổng số 116 đoạn khuếch đại, trong đó có 104 đoạn đa hình, chiếm tỉ lệ $89,65 \%$. So sánh kết quả của nghiên cứu này với các loại cây trồng khác cũng cho thấy mức độ đa hình của 11 chỉ thị ISSR trên cây điều tương đối phù hợp với nghiên cứu của Bharathi \& ctv. (2012) khi dùng 12 primer ISSR khảo sát trên các loài cây trồng thuộc trong chi Momordica và kết quả đạt tỉ lệ band đa hình là 93,2\%. Cũng trong báo cáo của Bharathi \& ctv. (2012) nhưng dùng 21 primer RAPD kết quả đạt tỉ lệ băng đa hình là $92,6 \%$. Tương tự, nghiên cứu Rasul \& ctv. (2007) sử dụng 44 primer RAPD trên 39 mẫu giống khổ qua hoang dại (Momordica dioica) và một mẫu gấc có kết quả là $95 \%$ band đa hình. Dey \& ctv. (2006) sử dụng 29 primer RAPD khảo sát đa dạng di truyền của 38 mẫu giống khổ qua và kết quả số đoạn đa hình chiếm tỷ lệ $36,5 \%$. Tỉ lệ đoạn đa hình của primer ISSR trong nghiên cứu cây điều được thể hiện cao hơn hiều so với các nghiên cứu được công bố trên các cây trồng khác như trên cây dó bầu (Vu \& ctv., 2014) dùng 12 primer ISSR và kết quả đạt 78,98\% band đa hình; Anil \& ctv. (2015) dùng 20 primer ISSR khảo sát 22 mẫu giống dưa gang (Cucumis melo var. momordica) thuộc họ Cucurbitaceae ở Ân Độ kết quả đạt 58,38\% band đa hình. Tương tự Verma \& ctv. (2015) báo cáo trên cây nghệ khi dùng 13 primer ISSR chỉ có có $82 \%$ band đa hình; Bharathi \& ctv. (2012) dùng 12 primer ISSR khảo sát trên 11 mẫu giống khổ qua và kết quả đạt 67,5\% band đa hình.

\subsection{Kết quả phân nhóm di truyền của các mẫu giống điều dựa trên chỉ thị ISSR}

Sự phân nhóm di truyền của 100 mẫu giống điều tại Bình Phước dao động từ 0,4 đến 0,26 , và các mẫu giống điều được phân chia vào 12 nhóm chính, tại giá trị trung bình khoảng cách đa hình di truyền là 0,19 (số liệu từ NTSYSpc2.1 - Hình 3). Trong đó, nhóm lớn nhất là nhóm I, cũng là nhóm tập hợp nhiều mẫu giống nhất (52 mẫu giống) với các mẫu giống được đánh giá có tiềm năng về năng suất như MD15, 24, 7, 23, 6, 12,11, 46, 43, 63, 64, 62 (Bảng 4, Hình 3). Nhóm lớn thứ nhì là nhóm VII, tập hợp gồm 25 mẫu giống, điều thú vị là tất cả 25 mẫu giống này được đánh giá là những giống giàu triển vọng, đang được thu thập và trồng lưu giữ tại Vườn sưu tập giống của Ban quản lý khu nông nghiệp ứng dụng công nghệ cao tỉnh Bình Phước (Bảng 4, Hình 3. Các nhóm còn lại chỉ bao gồm từ 1 - 6 mẫu giống, trong đó nhóm III, VI, XII chỉ duy nhất 1 mẫu giống.

\section{Kết Luận}

Dựa vào cây phân nhóm di truyền cho thấy 100 mẫu giống điều có tính đa dạng di truyền cao và được chia ra làm 8 nhóm dựa vào hai đặc điểm năng suất hạt và số hạt khô/kg. Trong khi đó, khi sử dụng 11 chỉ thị ISSR thì các mẫu giống điều được chia thành 12 nhóm riêng biệt, khoảng cách đa dạng di truyền từ 0,04 đến 0,26 , với giá trị trung bình khoảng cách đa dạng di truyền là 0,19 . Kết quả nghiên cứu này là nguồn thông tin rất hữu ích trong công tác đánh giá di truyền trên cây điều và phục vụ cho công tác chọn tạo và phát triển giống điều trong tương lai.

\section{Lời Cảm Ơn}

Nhóm tác giả gởi lời cảm ơn chân thành đến Sở KHCN tỉnh Bình Phước đã cấp kinh phí thực hiện nghiên cứu này, và cảm ơn tới các đồng nghiệp ở các địa phương nơi thu thập thập mẫu, cũng như các đồng nghiệp ở Ban quản lý Khu Nông nghiệp Ứng dụng Công nghệ cao tỉnh Bình Phước, và Trường Đại học Nông Lâm Thành phố Hồ Chí Minh đã hỗ trợ hoàn thành nghiên cứu này.

\section{Tài Liệu Tham Khảo (References)}

Aliyu, O. M. (2012). Genetic diversity of Nigerian cashew germplasm. In Mahmut Cahskan (Ed.). Genetic diversity in plants. Rijeka, Croatia: In Tech.

Anil, K. S., Sanjeev, K., Hemant, S., Ved, P. R., Brahma, D. S., \& Sudhakar, P. (2015). Genetic diversity in Indian Snap melon (Cucumis melo var. momordica) accessions revealed by ISSR markers. Plant Omics Journal 8 (1), 9-16.

Bharathi, S. K., Parida, A. D., Munshi, T. K., Behera, K. V., \& Raman, T. (2012). Molecular diversity and phenetic relationship of Momordica spp. of Indian occurrence. Genetic Resources Crop Evolution 59, 937948 .

Dasmohapatra, R., Rath, S., Pradhan, B., \& Rout, G. R. (2014). Molecular and agro-morphological assessment of cashew (Anacardium occidentale L.) genotypes of India. Journal of Applied Horticulture 16(3), 215-221.

Dey, S. S., Singh, A. K., Chandel, D., \& Behera, T. K. (2006). Genetic diversity of bitter gourd (Momordica charantia L.) genotypes revealed by RAPD markers and agronomic traits. Scientia Horticulturae 109, 2128 . 
Nakasone, H. Y., \& Paull, R. E. (1998). Tropical fruits. Oxford, UK: CAB International.

Rasul, M. G., Hiramatsu, M., \& Okubo, H. (2007). Genetic relatedness (diversity) and cultivar identification by randomly amplified polymorphic DNA (RAPD) markers in teasle gourd (Momordica dioica Roxb.). Scientia Horticulturae 111, 271-279.

Samal, S., Rout, G. R., \& Lenka, P. C. (2003). Analysis of genetic relationships between populations of cashew by using morphological characterization and RAPD markers, Orissa, India. Plant Soil \& Environment 49(4), 176-182.

Santhosh, W. G., Shobha, D., \& Melwyn, G. S. (2009). Assessment of genetic diversity in cashew germplasm using RAPD and ISSR markers. Scientia Horticulturae 120(3), 411-417.
Verma, S., Singh, S., Sharma, S., Tewari, S. K., Roy, R. K., Goel, A. K., \& Rana, T. S. (2015). Assessment of genetic diversity in indigenous turmeric (Curcuma longa) germplasm from India using molecular markers. Physiology and Molecular Biology of Plants 21(2), 233242.

Vu, T. H., Hoang, H. D., Pham, N. B., \& Chu, H. H. (2014). Genetic evaluation of Aquilaria crassna Pierre population in Vietnam using ISSR markers. Journal of Technology and Sciences 30(4), 23-30 